\title{
alphauille
}

\section{Scalarama 2016}

\section{Maria A. Velez-Serna}

Scalarama is a strange beast in the odd world of film festivals. Billed as "a celebration of cinema", its screenings do not necessarily, or mainly, take place in cinemas. There are no awards or limousines, no jury and no star curator. Instead, dozens of autonomous groups and individuals choose films they want to show, organise the logistics of licenses and spaces, and use Scalarama as a framework to make their screenings more visible and more viable. In principle, anyone wanting to show films in the month of September can be part of the Scalarama programme. Given this openness, the spontaneous coherence of the festival speaks of a shared understanding, not always explicit but articulated by the history and networks through which Scalarama connects.

Scalarama grew out of the "Scala Forever" season across several London venues in 2011. This was a eulogy to the Scala cinema, a legendary repertory cinema that peddled gore, hardcore, kung fu, exploitation and all sorts of disreputable film genres from a corner on King's Cross between 1985 and 1993. The underground affinities of this reference permeate Scalarama, although it is now a very different, idiosyncratic happening. The programming is seeded by the research and development work of Cinema Nation (run by Phil Foxwood and Michael Pierce), a community interest company that negotiates collective deals with distributors and offers ideas and support for new cine-club enthusiasts. This groundwork is not only of practical assistance, but is also a form of subcultural reproduction, ensuring a continuity for the more obscure corners of cinematic heritage that may not be legitimised by the education system or consecrated by the market. However, over the years Scalarama has diversified, welcoming new people who may not share the same type of cinephilia. This means that a documentary about skateboarders was as welcome as Bill Morrison's haunting montage of archive film set to Steve Reich's sound masterpiece, Different Trains (Bill Morrison, 2016); and Despicable Me (Pierre Coffin, Chris Renaud, 2010) could be on the same brochure as Santa Sangre (Alejandro Jodorowsky, 1989). What could have become purely a nostalgic affair catering to a rather niche demographic has mutated into an exploration of possible futures for the collective cinema experience.

Throughout the month of September, Scalarama included some two hundred events at over twenty cities and towns in the United Kingdom (and one in Budapest, apparently), in its ambition to "fill the land with cinemas". A festival report about this sprawling constellation can only be partial and situated. I write this from a Glasgow base, after attending more than half of the twenty-three screenings at thirteen locations in the city, ranging from a suburban living room to the Planetarium. I also managed to catch one screening in Liverpool and three in Leeds. This is still a tiny slice of the Scalarama pie, and does not intend to be representative of the UK-wide festival, although I do believe it is indicative. The highest level of Scalarama activity was in Brighton, with thirty-six screenings; the other cities, including London, were closer to Glasgow's numbers. In other respects Glasgow also seems fairly 
typical, with most screenings taking place at either a multi-arts centre or upstairs at a bar. These two types of venues account for a substantial number of the locations for the festival as a whole.

In Glasgow, the Centre for Contemporary Art (CCA) has long been a key point in the city's reinvention or rebranding as capital of culture. Its cinema and theatre spaces accommodate a growing number of film festivals, including SQIFF (Scottish Queer International Film Festival), SMHAF (Scottish Mental Health Arts Festival), Document International Human Rights Film Festival, Take One Action, Africa in Motion, Glasgow Short Film Festival, and many more. While these events become settled parts of the annual calendar, the "open source programming" policy operated by the CCA invites people to propose one-off events that, if approved by the curatorial team, can use the venue paying only staff costs. It thus offers a convenient and well-positioned cinema space for exhibitors without a venue. A similarly open door is offered by the Old Hairdressers, a city-centre pub, part of a chain of bars and restaurants that also function as important venues for Glasgow's live music scene. Its ascetic decor, a mix of reclaimed wood, sheet metal and bare concrete, offers a familiar grungy backdrop for a whole range of experimental and leftfield art and music projects. Cinema presence in the upstairs space has been increasing, with Fantom Cinema's intervention during Glasgow International in spring 2016 as a high point. Similar venues appear in the programme for other cities, suggesting a homology between DIY scenes that are structured around a few key meeting spaces. Scalarama makes visible some of the infrastructure that sustains an indispensable, but often overlooked part of the spectrum of cultural provision; one that is hard to quantify and that does not necessarily make financial sense. This is less about the exclusivity of the "pop-up" and more about the regularity of the cine-club, which attaches to particular spaces and where regulars may get to know one another.

What other cities have that Glasgow lacks is a permanent film space outside the multiplex/arthouse dichotomy, like Liverpool's Small Cinema or the Cube Microplex in Bristol, or even the beautiful Hyde Park Picture House, which were also Scalarama venues. The demise of repertory cinemas has been felt as part of the more general dismantling of urban "third spaces", the spaces of the kinds of casual community building that are so central to a sense of "scene". The interconnections between a certain type of venue, its passionate and somewhat codependent audiences, and the commercially motivated transformations of the film industry are explored eloquently in one of the emblematic titles in this year's programme. Julia Marchese's Out of Print (2014) looks at the endangered practice of 35mm exhibition through a series of interviews with the patrons of Los Angeles' New Beverly cinema. For the Glasgow screening, Analogue Film Scotland had to persuade the CCA to fix up their old projector. The film breaking halfway through the screening was almost an attraction in itself. Out of Print also played in London's Prince Charles and Genesis cinemas, the Duke of York's Picture House in Brighton, and the Curzon in Clevedon; the director toured with the film, having crowdfunded her trip in order to shoot new material for a documentary on independent cinemas.

Obsolete formats were also part of the appeal at one of the most successful Glasgow screenings: VHS Trashfest's triple bill, which closed with the preposterous, garish, shameless masterpiece Blood Diner (Jackie Kong, 1987). Copresented by local zine Physical Impossibility, VHS Trashfest gathered a large and appreciative audience - mostly male. This was not the same audience (considerably more female and younger) as the one that turned up for Beyond the Valley of the Dolls (Russ Meyer, 1970), also shown at the Old Hairdressers by 
a brand new cine-club, Something Weird; or as the one that filled the venue to capacity for Blueprint's excellent selection of independent animated shorts; or as the one that watched Vaghe Stelle dell'Orsa (Sandra, Luchino Visconti, 1965) followed by Sugar Hill (Paul Maslansky, 1974), in a genius juxtaposition programmed by Fantom Cinema. Of course, there are overlaps, but the divergences reflect the good health of DIY film exhibition in the city. Scalarama helped a couple of new cine-clubs to take the plunge and put on their first screenings, while also creating an intersection where new and established exhibitors could benefit from the network effect of cross-promotion and increased visibility. The local heart of the festival was Matchbox Cineclub, a monthly night run by Sean Welsh, who also acted as Glasgow Scalarama coordinator. Matchbox organised the closing party, for which the grunge atmosphere of the Old Hairdressers was enhanced with projected images of the walls of New York's CBGB, for a screening of DOA: A Rite of Passage (Lech Kowalski, 1980) followed by live bands.

Back in the CCA, Matchbox used their monthly slot at the CCA to show a "tropical gothic" film from Colombia, Pura Sangre (Luis Ospina, 1982). The more conventional cinema set-up generally conspired against the kind of looser socialising that characterised events at the Old Hairdressers. For instance, Sonder Cinema's screening of Valley Girl (Martha Coolidge, 1983) or Lightshow Film Club's "Rotten Kiwis" double bill seemed to call for some debriefing, but there was little incentive to hang around and chat once the lights were on. The habits of consumer cinema die hard, and less conventional screening spaces may be necessary to create opportunities for interaction. Conversation flowed more easily after the screening of Peggy Guggenheim: Art Addict (Lisa Immordino Vreeland, 2016) at Leeds' Arch Café, an unassuming building in a churchyard that keeps at bay the busyness of the surrounding streets. Ambient noise also sets a different expectation; in a bar like Leeds' Outlaws Yacht Club, the lack of complete silence or complete darkness did not detract from the film, but did preclude an immersive form of experience. At Metal at Edge Hill station, the trains rattling past created an eerie resonance with the on-screen images on Different Trains, as a reminder that the brutal history (the Holocaust) evoked by the piece is not fiction, it belongs in our universe and demands to be known. While all exhibitors are careful about the technical conditions of their screenings, it is clear that overwhelming cinematic spectacle is not what they are after. This is a cinephilia of sociability rather than form.

Not being in a cinema can in itself be an attraction. In Bristol, Sunset Cinema had outdoor screenings; the use of planetariums as cinemas also capitalises on the desire to watch film differently. On the other hand, plenty of bars, cafes and libraries use film to bring people through the door. Sloans, a traditional and touristic pub in the centre of Glasgow, hosts weekly movie nights for which the upstairs grand ballroom is equipped with professional projection equipment and food is served. The gilded magnificence of early-twentieth-century elegance, all mahogany and plaster, and a large bowl of macaroni cheese provide enough distraction to make the three-hour slog of Braveheart (Mel Gibson, 1995) just about bearable. Only a couple of blocks away from the Old Hairdressers, the tone of this is noticeably different, more bourgeois if you will, with its polite waiting staff and candle-lit tables for couples on a date night.

The most unusual locations were those of Radical Home Cinema. This project, conjured by the CinemaUP collective, invites people to host a screening at home. This experiment in blurring the boundaries between public and private film experiences had its first outing during the Radical Film Network festival, which took place in Glasgow at the beginning of May 2016. Some of the people who had volunteered their homes on that pilot 
programme repeated their participation during Scalarama; some have continued to host screenings on their own initiative. The hosts choose the films, and that choice becomes part of a demonstration of the extraordinary generosity of strangers. At Fourwalls, a housing cooperative founded by women, there were warm burritos and pancakes for a brunch-time screening of Born in Flames (Lizzie Borden, 1983). In the northern outskirts of the city, an Iranian dancer regaled us with cake and pistachios to mitigate the tragic stories of a featurelength cautionary tale about travelling to Australia (Journey, Mohammad Ghorbankarimi, 2016). I find out later that the beautifully shot, unrelentingly hopeless film by an Iranian director was commissioned by the Australian Government as a propaganda effort to deter migrants. Having watched it only half-attentively, as part of a chatty, intimate, and very international audience, while sharing a fellow migrant's hospitality, feels like the least harmful way of engaging with it. A few days later, in a West End flat, bowls of vegan snacks were passed around as we watched Reclaim the Streets (Agustin G. de Quijano, 2001) and Still We Ride (Andrew Lynn and Elizabeth Press, 2005). The artist and activist organising the screening then urged us to join Critical Mass. And why not? From these personal interactions and moments of kindness comes a greater sense of solidarity than that of mass demonstrations.

In the festival brochure, Amparo Fortuny of Radical Home Cinema writes: "you don't need to be cult, underground or committed, you can organise home screenings for fun, as an excuse to get to know your hot neighbour or just to celebrate the cinema together." Instead of the "sharing economy" (or the capitalism of self-exploitation), these simple acts of community building offer a different approach to autonomy and cooperation. This DIY in the plural is less about the individualism of subcultural distinction (although that never really goes away) and more about the joy of hospitality. As the Video Namaste bloggers wrote after VHS Trashfest, "[s]creenings like this are important as fuck." (Video Namaste). They nurture the spaces in which lasting social relations can emerge out of the throwaway contingency of a video projection.

\section{References}

Beyond the Valley of the Dolls. Directed by Russ Meyer, Twentieth Century Fox, 1970.

Blood Diner. Directed by Jackie Kong, Lighting Pictures/PMS Filmworks, 1987.

Born in Flames. Directed by Lizzie Borden, 1983.

Braveheart. Directed by Mel Gibson, Icon Entertainment, 1995.

Despicable Me. Directed by Pierre Coffin and Chris Renaud, Illumination Entertainment, 2010.

Different Trains. Directed by Bill Morrison, soundtrack by Steven Reich, 2016.

DOA: A Rite of Passage. Directed by Lech Kowalski, 1980.

Journey. Directed by Mohammad Ghorbankarimi, Put it Out There Pictures, 2016. 
Out of Print. Directed by Julia Marchese, Level Film, 2014.

Peggy Guggenheim: Art Addict. Directed by Lisa Immordino Vreeland, Dakota Group, 2016.

Pura Sangre. Directed by Luis Ospina, Focine, 1982.

Reclaim the Streets. Directed by Agustin G. de Quijano, 2001.

Santa Sangre. Directed by Alejandro Jodorowsky, Produzioni Intersound, 1989.

Still We Ride. Directed by Andrew Lynn and Elizabeth Press, In Tandem Productions, 2005.

Sugar Hill. Directed by Paul Maslansky, American International Pictures, 1974.

Vaghe Stelle dell'Orsa [Sandra]. Directed by Luchino Visconti, Vides, 1965.

Valley Girl. Directed by Martha Coolidge, Valley 9000, 1983.

Video Namaste. "On Tour, Live from the Field: VHS Trashfest, Glasgow 9/9/2016." Video Namaste blog, 11 Sept. 2016. videonamaste.blogspot.ie/2016/09/the-environment-inwhich-you-watch-film.html. Accessed 20 Dec. 2016.

\section{Suggested Citation}

Velez-Serna, Maria A. "Scalarama." Festival Report. Alphaville: Journal of Film and Screen Media 12 (Winter 2016): 141-5. Web. ISSN: 2009-4078.

Maria A. Velez-Serna is a Leverhulme Early Career Fellow at the University of Stirling, working on pop-up cinema exhibition. After obtaining her $\mathrm{PhD}$ at the University of Glasgow, she worked on the Early Cinema in Scotland project, and is coeditor of a forthcoming book on the subject. She has also published on Colombian cinema history and is a member of the HoMER Network (History of Moviegoing, Exhibition and Reception). 